\title{
2-Amino-9,10-Epoxy-8-Oxodecanoic Acid
}

National Cancer Institute

\section{Source}

National Cancer Institute. 2-Amino-9,10-Epoxy-8-Oxodecanoic Acid. NCI Thesaurus.

Code C1948.

The epoxy containing amino acid of HC toxin, a histone deacetylase inhibitor. 